\title{
An ever more violent world?
}

Kristian Skrede Gleditsch

University of Essex \& Peace Research Institute Oslo (PRIO)

Author's note: This manuscript is based on my inaugural lecture as the Regius Professor of Political Science, held on 16 October 2018. I am grateful to comments from the panelists participating in the roundtable (Kristin Bakke, Maria Fasli, Niall Mackay, and Andrea Ruggeri), the chair RT John Bercow, participants in the audience, as well as the support of the University of Essex in hosting and organizing the event. The material discussed here draws on collaborations with many other scholars, and my thinking on the broader issues discussed here has been influenced by many, including Lars-Erik Cederman, Aaron Clauset, Joshua Goldstein, Ismene Gizelis, Weisi Guo, Håvard Hegre, Nils Petter Gleditsch, Nils Metternich, Steve Pickering, Steven Pinker, Sara Polo, Gerald Schneider, Michael D. Ward, and Julian Wucherpfenning. 


\begin{abstract}
A recent report by the United Nations and the World Bank argues that the world has seen "a surge in violent conflicts in recent years”, with a sharp increase in reported battle-related and terrorist attacks, and calls for preventive action to ensure that increasing conflict does not undermine the UN Sustainable Development Goals. I will argue that this is a far too pessimistic assessment of conflict trends and not borne out the available evidence, which indicates a decline in violent conflict since the end of the Cold War. Alarmist warnings may seem helpful to call for action, but they detract attention from what we can learn about the causes for why conflict has declined. For example, resort to violence has become less frequent where factors that can motivate resort to violence such as political and ethnic exclusion have decreased. Moreover, conflict of interest does not imply violence, and the space for nonviolent alternatives has increased. The future of conflict and peace depends on our confidence in whether positive changes will continue and our understanding of the possible challenges.
\end{abstract}




\section{Introduction}

Since this is my inaugural lecture as the Regius Professor of Political Science, I would like to start by thanking the University of Essex, for awarding me the title, and Her Majesty the Queen, for agreeing to set up the position itself, and the recognition that this entails of my own field. I am of course flattered that I have been found to be suitable to hold this unique professorship in Political Science. But I would like to add that if I have accomplished anything as a political scientist, then this is also to a large extent because I have been fortunate to work in supportive environments such as the University of Essex, and I have also had excellent collaborators, including many former and current students who are here today.

Isaac Newton is often quoted on his statement that if he had seen further than others in his work then it was by "standing on the shoulders of giants". ${ }^{1}$ I very much agree that research is a cumulative process (see, e.g., Holt et al. 2016, Zinnes 1976). However, I do not think everything we achieve need to rest on the works of giants as such. In my view, an anthill is a much more helpful picture of how we typically build progress in science. We can achieve much more progress if we like ants focus on involving larger numbers of people and we all try to work together.

The specific topic that I would like to talk about here is whether we have clear trends in conflict, and whether we really have a more violent world as many seem to think. In answering this question, I will draw on a literal anthill of work, with research that I have conducted myself, often in collaboration with others, as well as many important things that I have learned from the contributions of other scholars.

${ }^{1}$ This quote appears in Newton's 1675 letter to Robert Hooke, available in digital form at https://digitallibrary.hsp.org/index.php/Detail/objects/9792. 


\section{An ever more violent world?}

Many people are definitely convinced that we are living in a very dangerous world with very serious threats to security. They also argue things are not just very bad at the present, they are also getting worse over time. The 2015 UK Strategic Defence Review, for example, stated that “threats to the UK country are growing” (p. 5). ${ }^{2}$ To justify this growth in threats it made references to the rise of the Islamic State, the greater general instability in the Middle East, and the crisis in Ukraine. At a meeting at the Royal United Services Institute earlier in 2018, Chief of the General Staff in the UK, General Nick Carter reaffirmed the analysis from the Strategic Defence Review. ${ }^{3}$ But he also warned that "threats have diversified and become more serious", and they had done so at a faster pace than anticipated. On the other side of the Atlantic, former Chair of the US Joint Chiefs of Staff General Martin Dempsey has gone one step further, and argued in a statement to the US congress that we live in a world "more dangerous than it has ever been” (for an extended discussion, see Preble and Mueller 2014).

It is worth pausing to digest exactly what this entails. If we take Dempsey's claim literally, then it would mean that the world at the present is more dangerous than during the peak of World War II, the deadliest conflict on record in absolute terms. It would also be more dangerous than previous periods of even more intense warfare in relative terms, or share of

\footnotetext{
${ }^{2}$ For the full text of the report, see https://assets.publishing.service.gov.uk/government/uploads/system/uploads/attachment_data/file /555607/2015_Strategic_Defence_and_Security_Review.pdf

${ }^{3}$ For the full transcript, see https://rusi.org/event/dynamic-security-threats-and-british-army.
} 
people affected, such as the Thirty Years War, where some European countries lost over a quarter of their population (Theibault 1997).

Some might argue that these statements about how we are currently living in dangerous times are based on things that could happen, rather than claims that we necessarily have a more violent world right now. ${ }^{4}$ But many similar claims also come up in analyses that claim to present data and analyses on actual violence.

For example, the so-called Global Peace Index by the Institute of Economic and Peace argues in the 2017 release of their report that violence is increasing, and that by their measure, only "10 countries ... can be considered free from conflict”. ${ }^{5}$ Moreover, the United Nations and World Bank (2018) recently published a new report called Pathways for Peace. The main purpose of the report is to advocate for more efforts to prevent violent conflict. But in trying to make a case for this they also highlighted how that violence is becoming more widespread and the world is more dangerous. The executive summary makes several strong claims, for example that "In 2016, more countries experienced violent conflict than at any time in nearly 30 years ... battle-related deaths have increased tenfold ... and terrorist attacks and fatalities ... rose sharply”. It warns that "If current trends persist, by 2030 more than half of the world's poor will

\footnotetext{
${ }^{4}$ For example, Dempsey acknowledges that we "live in an era where we're at an evolutionary low in violence" but holds that "the chance of violence and those using violence for ideological and other purposes is exponentially greater”, see quote in https://foreignpolicy.com/2012/11/14/dempseys-paradox/.

5 Se https://www.independent.co.uk/news/world/politics/global-peace-index-2016-there-arenow-only-10-countries-in-the-world-that-are-not-at-war-a7069816.html
} 
be ... affected by ... violence”. It also notes that this will make it hard to reach the United Nations sustainable development targets.

As a conflict researcher, I have spent a great deal of time developing and working with data on violent conflict. And I simply cannot reconcile these very pessimistic claims about a more violent and dangerous world with the data that we have. Rather, the data in my view confirm that conflict remains widespread, but if there is a trend over time, then it seems to be in the other direction, towards less conflict. But you do not need to just take my word for this over those of others - we can actually look at the data that we have on violent conflict.

Figure 1 shows a data set on instances of wars involving independent states from 1816 to the present, using an update version of the data described in Gleditsch (2004). The data are largely based on the definition of war suggested by the Correlates of War project, emphasizing conflict between organized armies, claiming more than 1000s battle deaths (Most and Starr 1983, Sambanis 2004, Small and Singer 1982). Figure distinguishes between interstate wars between states and civil wars where a state fights with a non-state actor. Each point in the bars in this figure is an ongoing conflict in that year, with color indicating the specific type.

Wars $(1000+$ deaths $)$

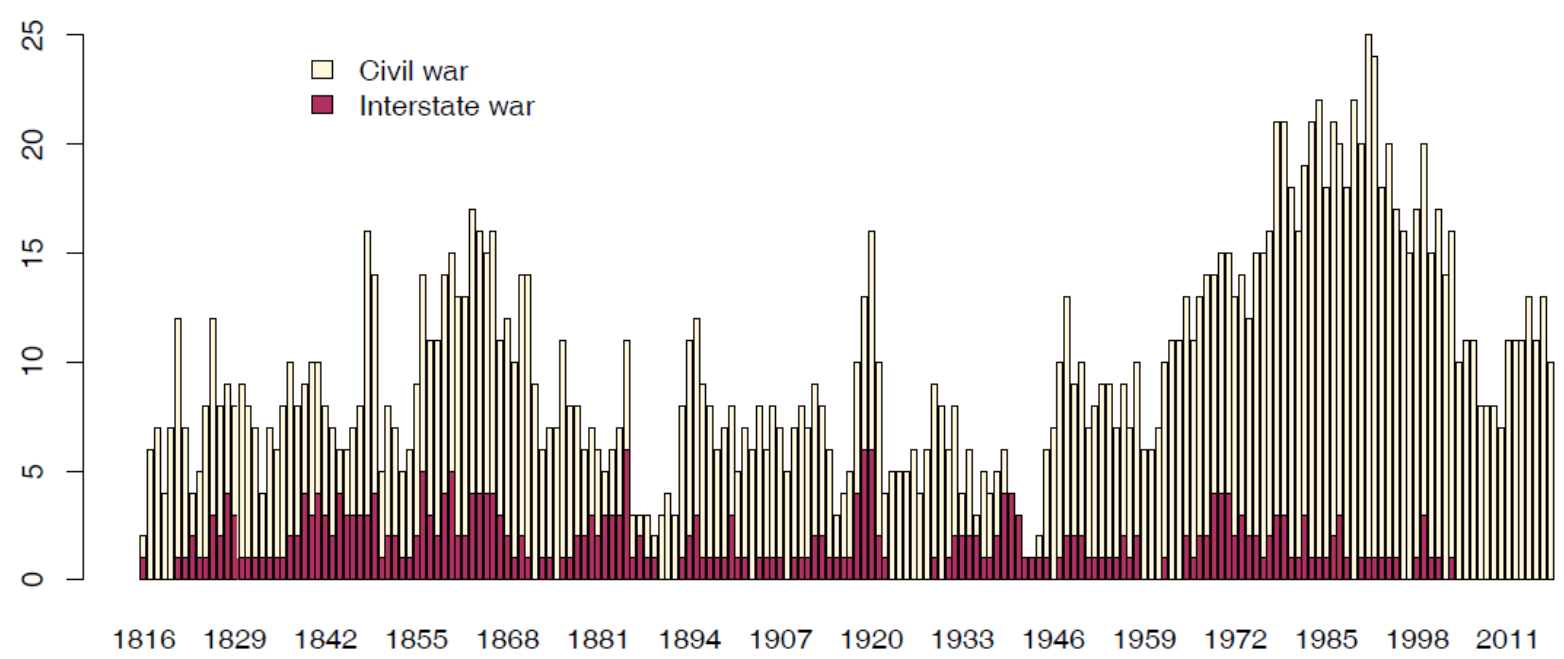

Figure 1: Distribution of interstate and civil wars, 1816-2017 
Figure 1 highlights a number of important changes in the number of wars over time. First, it is clear that interstate conflicts (shown in red) have never been very common. Yet, it is notable that we have not had any interstate conflict at the level of a war since the 2003 invasion of Iraq (see Gleditsch and Pickering 2014). Second, we can see that civil wars became more common with decolonialization after World War II (see also Miranda, Perondi and Gleditsch 2016). Third, we have a peak in the number of ongoing civil wars after the end of Cold War in the early 1990s. However, after this peak, we have seen a decline in the number of ongoing civil wars (see Cederman, Gleditsch and Wucherpfennig 2017). These trends are clearly not consistent with the claim that we live in an ever more violent world. Even if there is some increase after 2011, this is not enough to get the number of ongoing conflicts up to previous peaks. Finally, we can also see that wars and civil wars were common before World II and during the $19^{\text {th }}$ century. This is all the more remarkable since there were fewer established states and a lower population, and the record of violent events is probably much less complete, especially outside Europe.

So, how can people claim that we have more wars or that the present is particularly violent? One way to reach such conclusions is to use somewhat creative accounting, where one counts more violent events, or one consider more things as distinct conflicts or wars over time. For example, many people also include smaller violent events in counts of conflicts, or they differentiate between actors and aims in conflict to identify more distinct conflicts (see, e.g., Harrison and Wolf 2012). For example, some sources count all instances where the Islamic State carries out terrorist attacks in different states as separate civil wars since they fight different 
governments. ${ }^{6}$ There could be good reasons for these types of measures or refining our definitions, and casting the net wider than the wars or the most severe violent conflicts. But if we want to look at trends then we must be consistent over time, and we should be skeptical of apparent trends that may be due to changes in the standards applied (see Gleditsch and Beardsley 2010).

Instead of trying to make decisions about what constitutes a distinct conflict and counting each war irrespective of its size as a single data point, we can look at a simple measure of the total number of people killed in warfare (see Richardson 1960). If we consider the fatalities in war, then we also see no evidence for the assertion that the contemporary world is more dangerous. If anything, the decline in the number of warfare casualties seems even more dramatic.

Figure 2 shows data on deaths in a wider range of violent conflicts from the Uppsala Armed Conflict Data, and this also includes armed conflicts with less than 1000 battle deaths (see Gleditsch et al. 2002). But even using this wider definition, we see a decline rather than an increase in the number of battle deaths. We can also see that here the decline in deaths starts earlier, before end of the Cold War. Of course, the current civil war in Syria is a very severe conflict, and we see some upward movement at the end of the period. However, the number of people killed overall remains lower than in earlier decades, and the Syrian civil war is not as severe as previous wars such Iran-Iraq war in the 1980s, where many sources such as the

${ }^{6}$ For a discussion of how this is handled by the Uppsala Conflict Data Program, see https://www.pcr.uu.se/research/ucdp/faq/. 
Correlates of War project has estimated that as many as 1.25 million died in combat. ${ }^{7}$ Hence, regardless of whether we look at counts of wars or deaths based on the most direct measure of severity, there is simply no evidence that we see more violence due to warfare. Rather, the data indicate that the violence observed has declined.

\section{Battledeaths (in 1000s)}

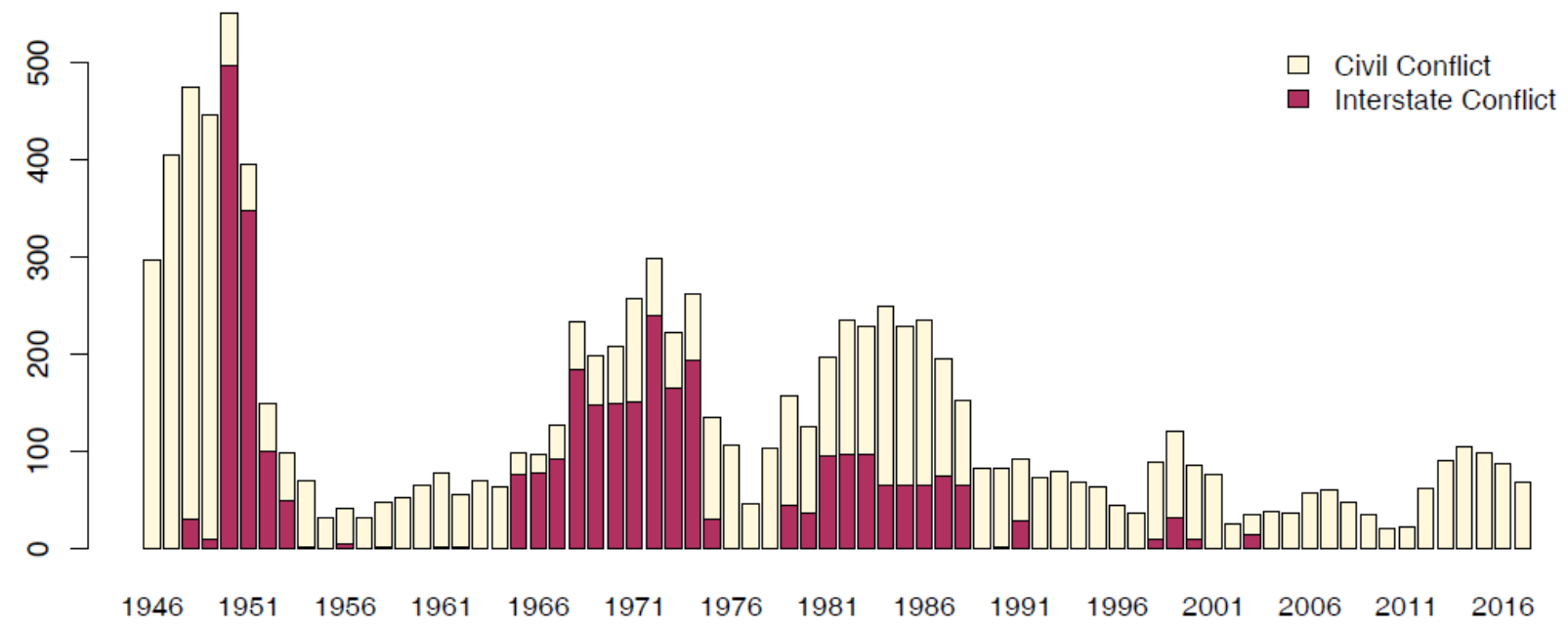

Figure 2: Battledeaths in war, by type, 1946-2017

Some people argue that it is misleading to look only at traditional warfare or conventional conflict. They claim that we have had a transformation of war, where the "old wars" have given form to "new wars", with unconventional forms of conflict such as terrorist tactics becoming more widespread (Gray 2015, Kaldor 2006, Mann 2018). We can find some apparent support for this view in the available data on terrorism. The so-called Global Terrorism Database (LaFree and Dugan 2007), for example, clearly appears to report a higher number of terrorist attacks over

7 For a discussion of the death toll estimates for the Iran Iraq conflict, see https://kurzman.unc.edu/death-tolls-of-the-iran-iraq-war/. 
time, especially since the mid-2000s. ${ }^{8}$ Figure 3 displays the total number of attacks most recent version of the GTD data.

Terrorist attacks

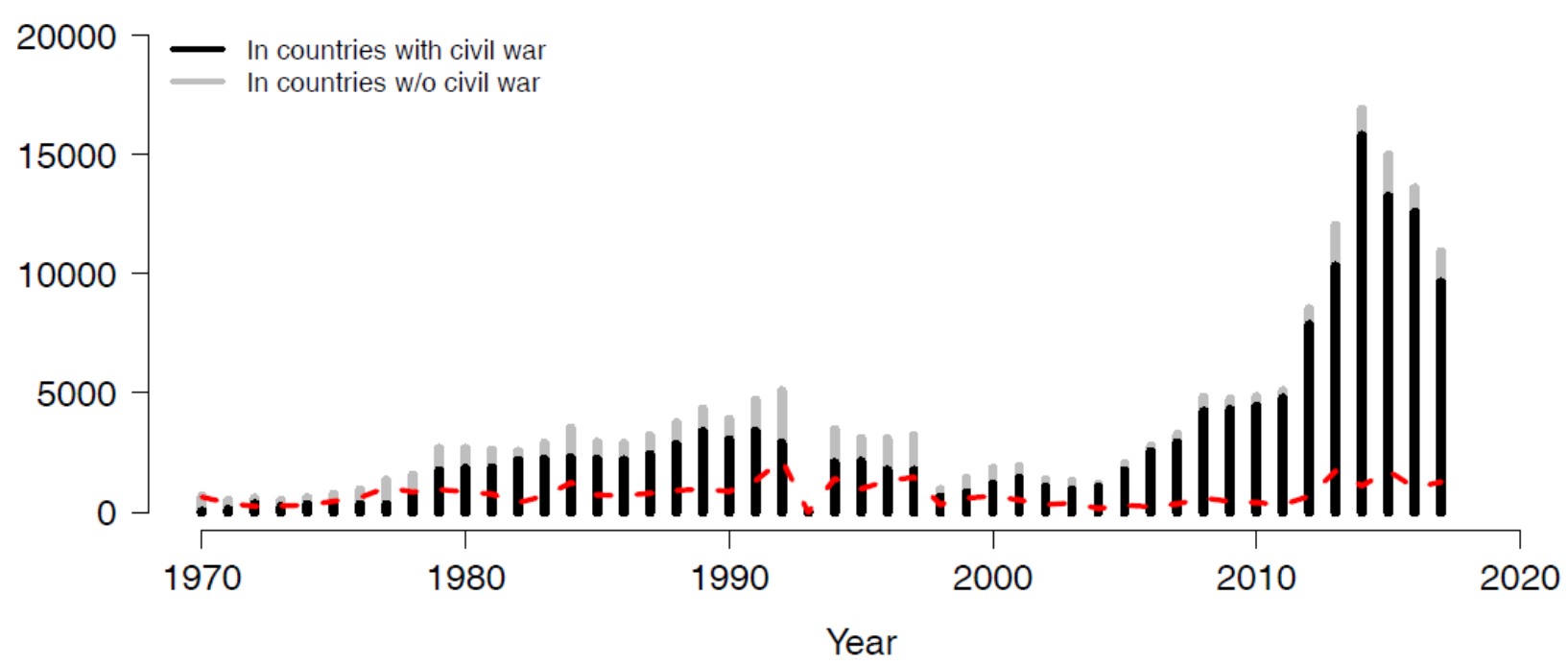

Figure 3: Number of terrorist attacks, with shading by whether the location country is involved in a civil war or not

However, there is really no evidence in these data that we have an explosion of terrorist attacks instead of conventional civil war, as the strict version of the New Wars thesis suggests. Once we start inspecting the underlying data, then it becomes clear that most of the events reported in the Global Terrorism Database are attacks in countries already at civil war. In

8 For an alarmist headline making this point, see https:/www.theguardian.com/uknews/2014/nov/18/fivefold-increase-terrorism-fatalities-global-index. However, subsequent releases acknowledge that terrorism overall has declined, see e.g., the discussion in https:/www.washingtonpost.com/world/2018/08/15/terrorist-attacks-are-quietly-decliningaround-world/?utm_term=.468f0a32311e. 
particular, the bulk of the events are attacks that place in Afghanistan and Iraq. In Figure 3 have shaded black all the attacks that place in countries in civil war. We can see that this includes most events and the proportion is actually increasing. If we look at the residual grey area on top which are the attacks in countries without civil war, then we see a limited number of events and no clear increase in attacks. If we look at the absolute numbers for these events alone, shown as the dashed red line, then there is no trend. Hence, if we have more terrorism, then it is only because we have more attacks in ongoing civil wars. ${ }^{9}$

Some have also argued that we have more reported terrorist attacks because we now interpret more outbreaks of violence as terrorism (see Human Security Report 2007). For example, in the past, many would have considered the events included in Afghanistan and Iraq as guerrilla attacks or violence against civilians. Moreover, most recorded terrorist attacks are not lethal, and there is no evidence that terrorism is becoming more lethal. If anything, terrorist attacks tended to be more severe in the 1980s, when bombs placed on aircrafts such as in Lockerbie disaster were more common (Sandler 2014).

\section{Why is pessimism so pervasive}

This pervasive pessimism about the state of the world is not confined to war and peace. The Gapminder project started by late Swedish physician Hans Rosling conducts a multiple choice survey on global health and development (https://www.gapminder.org/, see also Rosling 2018).

\footnotetext{
${ }^{9} \mathrm{I}$ am currently engaged in collaborative research on why this may be the case with former students Sara Polo and Andrea Ruggeri. One important explanation seems to be that we have more asymmetric civil wars that favor terrorist tactics by weak rebels against much stronger opponents on the government side (see also Polo and Gleditsch 2017).
} 
This includes a series of factual questions on such issues as the current global average life expectancy and the change in the share of the world's population living in extreme poverty over the last twenty years. Here, we also find that the answers people give tend to be far more pessimistic about the outcomes than the data on the actual state of the world. For example, most respondents believe that the current average life expectance is much lower than the actual 70 years. And most people believe that poverty has been rising, even though it has actually halved.

This survey has been conducted in many countries and many different settings, including audiences such as students, bankers, politicians, health activists and even Nobel Prize laureates. The respondents all do consistently worse than a random guess, or the share of correct response we would expect if they had been submitted by the proverbial chimpanzee throwing darts at the score board. But they are also wrong in a very consistent manner, on the side of pessimism. A YouGov survey found that the number of pessimists who think world is worse outweigh the number of optimists who think things are getting better in all countries examined, save for China. $^{10}$

Why pessimism is so ingrained in us is a question outside my own area of expertise, and I will not dwell on it at any length here. But one likely important factor is media bias. Bad news is more likely to be deemed newsworthy than good news. ${ }^{11}$ As a result, we are more likely to see reports on crises breaking out on the front page than reporting on conflicts that did not occur. Moreover, the positive long term trends - if at all covered - will at most show up in the back

\footnotetext{
${ }^{10}$ See https://yougov.co.uk/topics/politics/articles-reports/2016/01/08/fsafasf.

11 See, e.g., https://www.theguardian.com/commentisfree/2018/feb/17/steven-pinker-medianegative-news.
} 
pages. For this reason, data and statistics are important to provide an antidote to the salient but often atypical anecdotes.

Many people are also afraid that not stressing the negatives enough could lead to complacency and potentially become an excuse for lack of action. Obviously, it is important to be concerned over real problems such the ongoing violence and risk of war. But the major problem in just stressing reasons to be afraid and risks is that the road to sinister places often can be paved with very good intentions. I will return to this point later.

\section{Documenting the decline of war and its possible causes}

By now we have a large body of research on this decline of violence, popularized by books by prominent writers such as the psychologist Steven Pinker (2011) and political scientist Joshua Goldstein (2011). Both came to the University of Essex in September 2013 to receive the Book of the Year award from the Conflict Research Society. ${ }^{12}$

In addition to conventional violent conflict events, we also have similar evidence of declining violence in other data sources, including violent crime, as well as clear changes in peoples' views on when it is acceptable to use violence (Pinker 2011). For example, there was a time when physical punishment of students would have been considered perfectly normal. That is clearly not the case now (Gershoff 2017). Surely both I and my students alike consider this to be a very good thing.

But some critics insist that observing a trend is not the same as establishing changes in risk (Cirillo and Taleb 2016, Taleb 2007). One might argue that we have simply been lucky, and the decline in violence that we see could just reflect random variation. For example, under a

\footnotetext{
${ }^{12}$ See http://conflictresearchsociety.org/the-conflict-research-society-book-of-the-year/
} 
slightly different turn of events, the Cuban Missile Crisis could have escalated to a war between the superpowers, and possibly even with the use of nuclear weapons (Lebow 2009).

We tend to think of history as the study what happened, and the idea of trying to study what could have happened is somewhat alien to many (Fearon 1991, Fergusson 2011, Tetlock and Belkin 1996). One way to consider variation more explicitly is to use more formal statistical models of risk of different types of conflict, based on the observed data. We can then use such models to assess the fit with observed data, derive expected outcomes for new periods, examine how likely changes in observed outcomes would be under a model, or assess how strong the observed evidence is for fundamental shifts or changes in the underlying distributions such as the likelihood of conflict or conflict of a particular severity or magnitude (see, e.g., Clauset, Young and Gleditsch 2007, Clauset and Woodard 2013, Clauset 2018, Gleditsch and Clauset 2018). This line of work was pioneered by Lewis Fry Richardson, a British physicist and meteorologist, who was one of the first to study war and peace from a mathematical perspective (see especially the set of articles later published as Richardson 1960).

Richardson's work on the study of conflict distributions and trends was never mainstream. It remained ignored and peripheral to mainstream conflict research for a long time, in part because so many traditional theories of conflict such as realism take as their foundational premise that the world just does not change and that the war is inevitable, either due to human nature or some form of underlying laws of power. However, trends and comparisons to distributional models has now become an active field of research again in light of the interest in the decline of violence.

Many of the recent debates here are quite technical, but I would like to highlight two important findings. The bad news is that because the severe wars are very rare, it is also very 
difficult to say much about declining risk, just because we have not observed a large war for some time. For example, my occasional collaborator Aaron Clauset (2018) has estimated that we would need at least 100-150 years without major war before we could reliably conclude that the risk of severe conflict or a new WWIII had declined. ${ }^{13}$

However, the second important finding is that there is also better news in that we have more general evidence of structural breaks in the frequency of outbreaks of conflict events. I have found in collaborative research evidence that supports a phase transition that we have entered a period with less frequent outbreaks after the late 1990s (Cederman, Gleditsch and Wucherpfennig 2017). Other scholars from many fields including Mathematics are also doing important work that suggests more evidence for qualitative changes (see Fagan et al. 2018). ${ }^{14}$

However, since the focus has been so centered on whether we have a trend or not, we have learned less about the possible causes of the declining trend. I think this is important in its own right in order to assess risks or judge how dangerous the world is. Whether we can have confidence in trends continuing depends on our understanding of causes and whether the

${ }^{13}$ His article was picked up by some newspapers in the UK, and the Express chose to publish a summary with the headline "Mathematician predicts that world war III is overdue", see https://www.express.co.uk/news/world/923288/brink-of-war-world-war-3-world-war-2-1945long-peace. This is not quite what the article actually says, but the important point remains that it is difficult to rule out changes in the likelihood of an infrequent event, and that the risks can remain high even if we do not see one for long periods.

14 For an overview and discussion of ongoing research and a roundtable, see https://www.mn.uio.no/math/english/research/projects/focustat/the-focustatblog!/krigogfred.html 
supporting factors for peace will persist. Also, if we have done something right, we need to know what it is in order to do more of it (see Mack 2002).

\section{Understanding the decline of ethnic conflict}

Conflicts can come in many types and have many different causes. I will here focus on a specific type of conflict, namely ethnic civil war, where we have better sense of key important causes (see Cederman, Gleditsch and Buhaug 2013). In our book on ethnic civil war (Cederman et al 2013), we stressed inequality and the grievances they give rise to as key causes of violent ethnic conflict. Ethnic inequality can be both political or economic. An ethnic group may be systematically excluded from political influence in a state. Likewise, ethnic groups can be economically disadvantaged relative to dominant or privileged groups. Ethnic civil wars are important in terms of both absolute numbers and relative share. Until recently it has consistently been the case that more than $50 \%$ of ongoing civil wars involved distinct ethnic groups in conflict with a state (Cederman, Gleditsch and Wucherpfennig 2017). These conflicts typically center over claims for secession for a territory or greater autonomy. The growth we have seen in civil war after decolonization was overwhelmingly composed of ethnic civil wars.

So, if inequality can motivate grievances and violent conflict, then is it also the case that we have had a decline in exclusion, and could this explain the decline in conflict? In order for this to be the case, we would need to have both a decline in motivating factors, and there would have to be discernably less conflict in the countries where we have had declines in exclusion. Cederman, Gleditsch and Wucherpfennig (2017) show that this indeed is the case for instances where we have decreases in political exclusion. Figure 4 shows the average size proportion for ethnic groups that fall in different political status categories in a common data set called Ethnic 
Power Relations (Vogt et al. 2015). These data indicate how ethnic groups can be excluded from political power or actively discriminated against. Alternatively, ethnic groups could be included and have access to political power. Beyond cases where a single group is dominant, we could also have powersharing between multiple groups, which we can think of as a form of ethnic pluralism as in countries such as Belgium. The size of groups matters since larger groups are more likely to have resources to fight against the state. Thus, groups that are large and excluded have both sufficient resources and motivation to rebel. Figure 4 shows that greater ethnic political inclusion and equality has become more common and widespread over time. The share of groups in exclusive outcomes has declined, and the most severe form of discrimination is also much lower. By contrast, we have a clear increase in the proportional size of groups involved in some kind of powersharing.

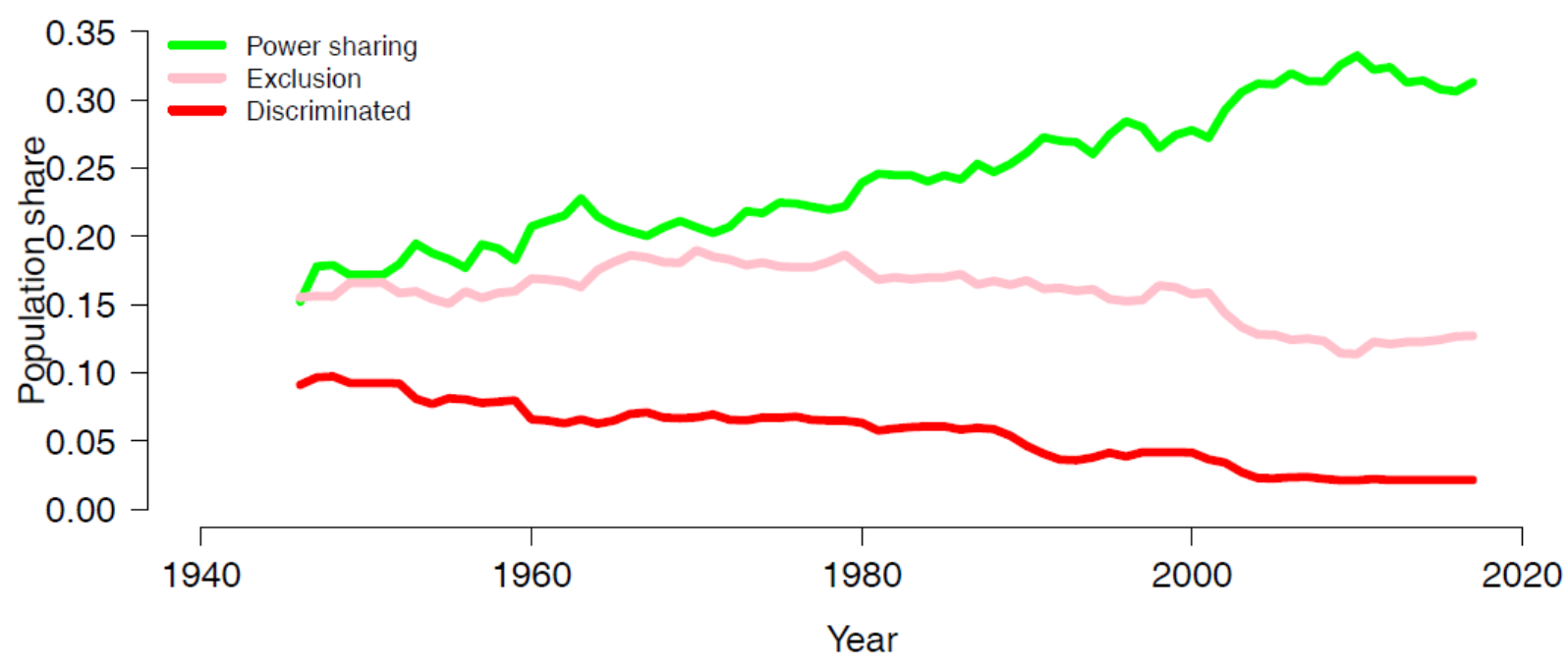

Figure 4: Trends in ethnic exclusion and power sharing

The degree to which political institutions are democratic and allow political competition, also determines whether groups can pursue their aims by peaceful political means. Violence 
becomes more likely when these opportunities do not exist in an autocracy. Figure 5 shows the proportion of countries considered democratic, using a common database on democratic institutions called the Polity data (Gleditsch and Ward 1997, Jaggers and Gurr 1995). Here again we can see that we have had an expansion of countries with democratic rule. From the perspective in our 2013 book (Cederman et al. 2013), we would expect these changes to be reflected in less violent ethnic conflict and more peaceful competition.

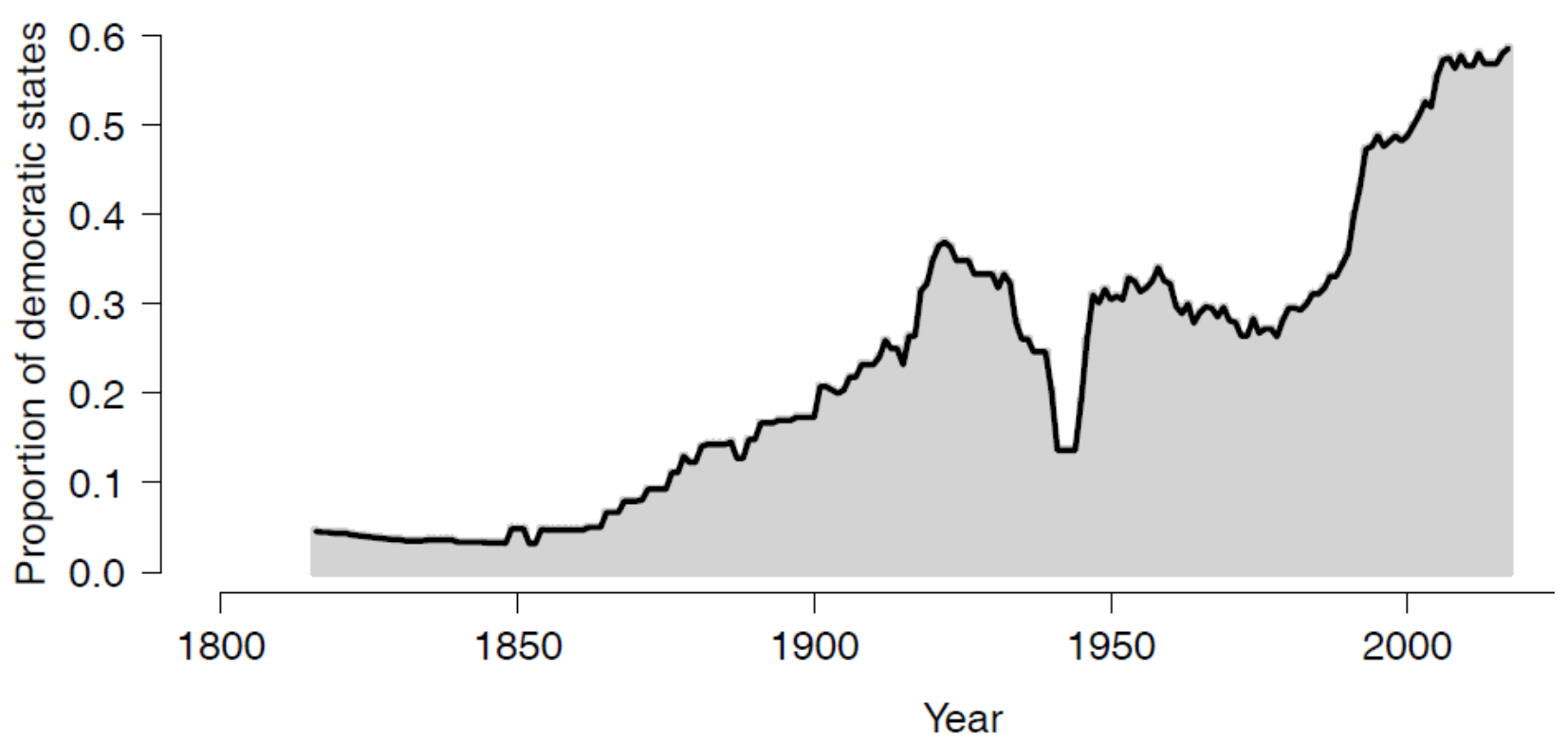

Figure 5: Proportion of states considered democracies

In Cederman et al. (2017) we try to look specifically at the cases where the status of ethnic groups have seen improvements, and then compare if we have fewer new violent conflict outbreaks and more conflicts termination there afterwards. And we indeed we find less conflict and more termination in cases where we have seen positive changes. Thus, the theory of inequality, exclusion and civil war is helpful not just to understand which countries see conflict, but also to reveal the possible conflicts that did not break out because the world changed. 
To many, the idea of studying things that do not happen may seem odd and perhaps rather speculative. But much of our important knowledge is of this type. We have all been told to wear seatbelts and that this save lives. Indeed, we currently get fined between $£ 100$-500 if we do not wear them while driving, and the UK government has since 2012 maintained a campaign called THINK! aimed at encouraging increased use. ${ }^{15}$ But how do we know that lives are saved, and how do we know how many lives may have been saved from the use of seatbelts?

Remember that lives saved are accidents that could have been fatal but ultimate were not because something changed. In short, the estimates of lives save are roughly derived as follows: We compute a baseline fatal accident rate, with and without seatbelts. We then compute the difference based on the real world with seatbelts, and what we would see in a hypothetical world where the same number of trips are done and we have the same accident rate, but without the use of seatbelts. ${ }^{16}$

Just as we both can and should evaluate the effects of seatbelts on road fatalities, we can think of conflicts that do not happen because of political reforms as a similar type of prediction problem. Cederman et al (2017) considers this by comparing estimates from two model and observed data and then comparing these to a forecast into the future. If we think of future trends as just as a mechanical extension of the past up to 1999, how much war would have expected to see in the following years? In Figure 6, this trend prediction, based on data up to 1999, is shown as dashed line in sample. We then show as an orange line the forecast derived from this for the

\footnotetext{
${ }^{15}$ See https://www.gov.uk/government/publications/think-seat-belts.

${ }^{16}$ For a more detailed overview of the methodology, see the report from the US Department of Transportation National Highway Traffic Safety Administration at https://crashstats.nhtsa.dot.gov/Api/Public/ViewPublication/811206.
} 
subsequent years after 1999. We can see that we would have expected to observed a consistent high number violent ethnic conflict to remain high, without any real decrease over the period. We can then compare this to the predictions that we would get from a model that considers ethnic accommodation. This is shown as a solid line in the period up to 1999, and then as a green line in the forecast period after this. In the observed data period up to 1999 we do not see much divergence between the two model predictions, but they start to diverge after the Cold War, and dramatically so in the forecast period after 1999. Not only does the model taking into account ethnic accommodation predict a downward trend. It also fits better with the observed data, here shown as grey vertical bars for the number of conflicts. Thus, the evidence is consistent with more ethnic accommodation in this period leading to ethnic fewer civil wars.

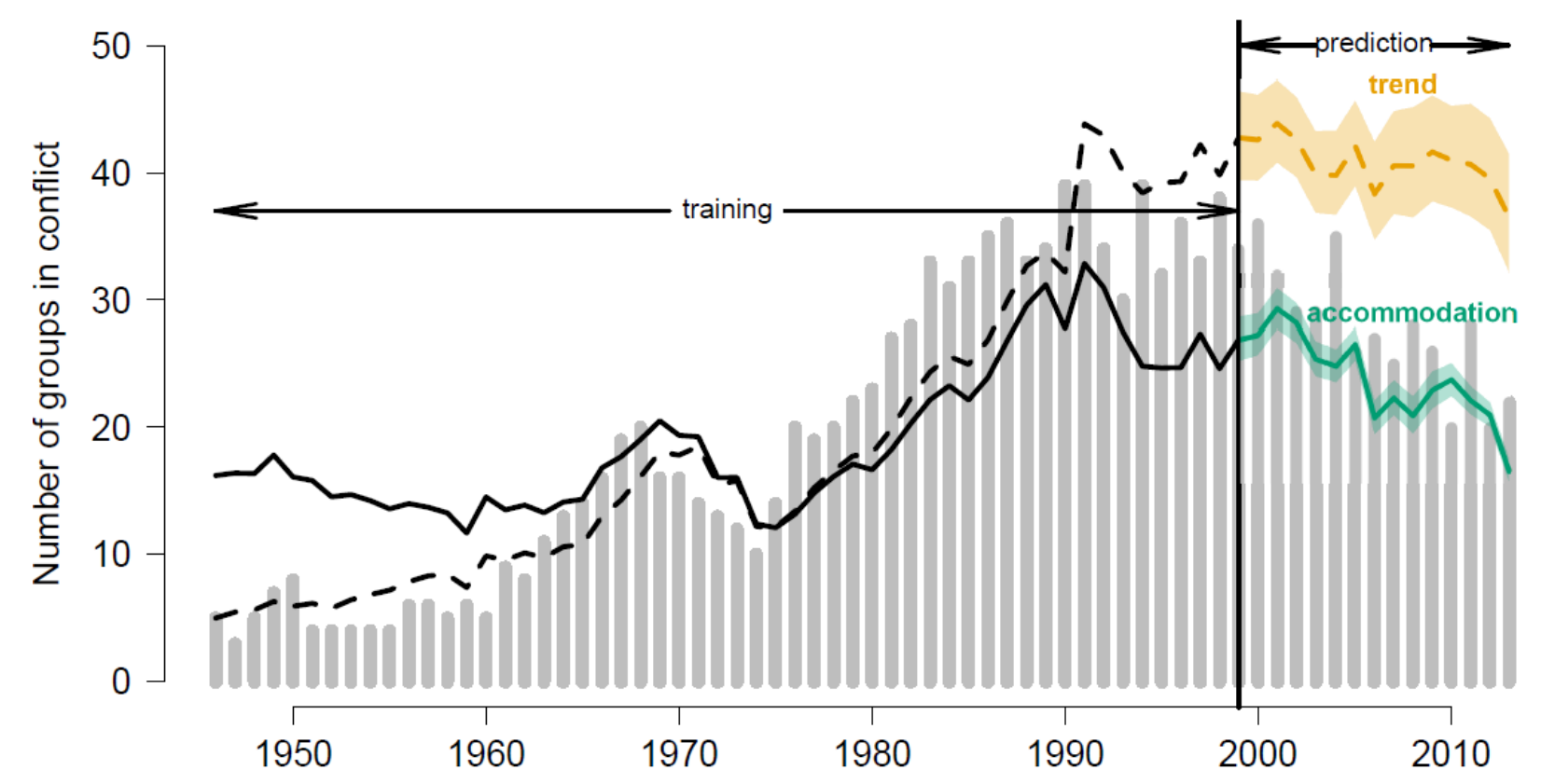

Figure 6: Trend versus accommodation model post 1999 predictions and data, from Cederman et al. (2017) 
Some may contend that perhaps the declining trend and positive influences could be true for conventional civil war, but what about terrorism and the other security risks that many think we face here in the UK? Here, I would like to make two points. First, much of the terrorism in European countries currently emerges from civil war outside Europe. Thus, efforts to reduce the extent of civil war elsewhere can help to stem the risk of terrorism. Second, we can also see from the data in Figure 7 that we have that we have had much more terrorism in the past history of Europe, in particular during the 1970s and 1980s.

Much of the terrorism at the peak was ethnic, involving groups such as the Corsicans in France, German speakers in Italy, or Catholics or Republicans in Northern Ireland (Engene 2005, Engene 2007, Gleditsch and Polo 2016, Polo and Gleditsch 2016). These ethnic conflicts did not become full civil wars and involved limited total battledeaths, but many groups such as the Republicans in Northern Ireland waged major terrorist campaigns. Indeed, the IRA campaign also involved attacks in places close to where we are today, such as Colchester Garrison.

Gleditsch and Polo (2016) also find that the volume of ethnic terrorist attacks also declines after accommodation of ethnic groups. Our interpretation is that even if changes such as autonomy in Corsica and the Good Friday agreement do not satisfy the extremist, they do curtail recruitment, and this eventually decreases the number of attacks, even if the number of terrorist attacks may not go to exactly 0 . We think this has more general applications for other types of terrorism too, including right-wing terrorism or Islamist groups.

To be clear, terrorism is a serious problem, but if anything it seems less severe at the present than the past in Europe. There is little to justify elevating it to existential threat now, or to proclaim that we have clear growing risks of terrorism (see also Mueller and Stewart 2011, Mueller and Stewart 2015). 


\section{Fear of complacency vs. the perils of faith based policy}

Some people may argue that it is important to be worried about conflict to avoid complacency and lack of action. Clearly the press release for the United Nations and World Bank (2018) report on Pathways for Peace hoped that highlighting a bleak picture could help attract more interest and promote action. I agree that international efforts can play an important role in containing violent conflict, but it is not enough to just to have good intentions to do well.

For example, during the Black Death in the 1300s it was common to think that disasters reflected sin. It was widely believed that the plague must be a punishment from God. If so, then it seems logical that the solution would be to show more devotion and pray, as confidently expressed in a quote from Bishop Edendon of Winchester in $1348 .{ }^{17}$

this cruel plague has now begun a similarly savage attack upon the coastal areas of England. ... Sickness and premature death often come from sin and by the healing of souls, this kind of sickness is known to cease.

Bringing people together to pray during the plague was clearly well intended. However, we now know that it was also counterproductive, as it promoted the spread of disease through human transmission (Dean et al. 2018). Clearly, good intentions alone do not guarantee good outcomes.

This is true also in foreign policy. For example, the UK and France may well have had sincere intentions to protect civilians when they decided to launch a bombing campaign against in Libya in 2011. There was an impetus to do something, and surveys at the time suggested that proposals to bomb could have considerably popular support. However, in retrospect this seems very much like a faith-based initiative, without much assessment of the threat or consequences of

\footnotetext{
${ }^{17}$ Quoted on http://www.bbc.co.uk/history/british/middle_ages/blackdisease_01.shtml
} 
actions. The Foreign Affairs committee's 2016 inquiry of the decision produced a report that was extremely critical. ${ }^{18}$ They argue that the campaign was conducted without any proper intelligence analyses or assessment of threats and consequences. The mission then drifted into an unannounced goal of regime change, with no prior debate. Moreover, it was noted that the intervening powers simply lost interest in the outcome following the fall of Gaddafi.

Libya should be a chilling reminder that doing something well-intended could make things worse. Likewise, we are not taking conflict in any way more seriously by being more afraid of it. Indeed, stocking fear tends to produce paralysis or rash decisions rather than the rational and considered action that we seek. A better approach is to try to monitor the data to better to understand what has happened and to use data in ways that can help evaluate what can be done and likely consequences. Just as some data is better than anecdotes, more data can be much better then anecdotes. I have emphasized data on simple large-scale trends. However, we now have new sources of big and more detailed data on events in conflict, and other information such as information satellite data and news media can play in important role providing more realtime information on conflict and actors. Of course, we need to understand the way that data becomes available to us and the possible filters in how information reaches us, but they open tremendous opportunities for more detailed analysis (see Guo, Gleditsch and Wilson 2018).

Beyond showing trends in conflict and that the world is not ever more violent, I hope that I have convinced you of the value of looking at specific reasons for why conflict has declined. It is important to understand why we have had a decline in conflict precisely to identify what we may have done right, and how we may do even better (e.g., Mack 2002). We can make violence

\footnotetext{
${ }^{18}$ For the full text, see

https://publications.parliament.uk/pa/cm201617/cmselect/cmfaff/119/119.pdf.
} 
more difficult for non-state actors by shoring by up the military capacity of states, as in the classic logic of deterrence and making conflict costly. But we can also make violence less attractive and likely by reducing motivation, and more ethnic accommodation is an important explanation for the decline of conflict (see Cederman et al. 2017). Similar perspectives on other varieties of violent conflict can also at least in principle help understand non-ethnic motives, why ongoing conflicts persist, and what would influence the actors to change their tactics.

Policy relevance is ultimately a question of policy priorities and objectives. Research has much to tell us about means-ends relationship given objectives, but the specific objectives themselves must be specified in advance (Bueno de Mesquita, Newman and Rabushka 1985, Elster and Skog 1999, Manski 2013). Researchers can of course participate in debating what policy goals ought to be, but they have no particular competence in this area, nor should they hold a privileged position over others in determining goals or policy objectives. Many foreign policy controversies center on the weight that should be assigned to different priorities, and there is often an unclear mix of often competing objectives. How much should you emphasize minimizing violence or stability over promoting political change, for example, has surfaced repeatedly on debates on foreign interventions in Afghanistan and Syria.

In the sustainable development goals many things are lumped together. Sustainable Development Goal number 16 alone for instance combines peace, justice and strong institutions. ${ }^{19}$ These outcomes may all be important priorities, but they are clearly not the same. If we can get all at the same time then that is of course great, but there may well be cases where one objective can be in conflict with another or potential trade-offs.

19 http://www.undp.org/content/undp/en/home/sustainable-development-goals/goal-16-peacejustice-and-strong-institutions.html 
Still, in some cases the debates are, or at least should be, over the likely consequences, as in the case of Libya. Here, more structured predictive research can be very helpful. If we want to evaluate how say mediation or peacekeeping could have prevented escalating conflict, then we should try to use our knowledge about the past and devise explicit predictions and scenarios to justify the likely consequences (see Beardsley and Gleditsch 2015, Hegre, Hultman and Nygård 2018). Politics may not be a science, but we can study politics scientifically. Political science cast this way can help clarify debates and disagreement and also inform politics. On this note, I conclude my lecture, and thank again for being awarded this professorship as well as your interest in this lecture. 


\section{References}

Beardsley, Kyle and Kristian Skrede Gleditsch. 2015. "Peacekeeping as Conflict Containment." International Studies Review 17(1):67-89

Bueno de Mesquita, Bruce, David Newman and Alvin Rabushka. 1985. Forecasting Political Events: The Future of Hong Kong. New Haven, CT: Yale University Press.

Cederman, Lars-Erik, Kristian Skrede Gleditsch and Halvard Buhaug. 2013. Grievances and Inequality in Civil Wars. Cambridge and New York: Cambridge University Press.

Cederman, Lars-Erik, Kristian Skrede Gleditsch and Julian Wucherpfennig. 2017. "Predicting the Decline of Ethnic Civil War: Was Gurr Right and for the Right Reasons?". Journal of Peace Research 54(2):262-74.

Cirillo, Pasquale and Nassim Nicholas Taleb. 2016. "On the Statistical Properties and Tail Risk of Violent Conflicts." Physica A: Statistical Mechanics and its Applications 452(15):29-45.

Clauset, Aaron, Maxwell Young and Kristian Skrede Gleditsch. 2007. "On the Frequency of Severe Terrorist Events." Journal of Conflict Resolution 51(1):1-31.

Clauset, Aaron and Ryan Woodard. 2013. "Estimating the Historical and Future Probabilities of Large Terrorist Events." Annals of Applied Statistics 7(4):1838-65.

Clauset, Aaron. 2018. "Trends and Fluctuations in the Severity of Interstate Wars." Science Advances 4(2):10.1126/sciadv.aao3580.

Dean, Katharine R., Fabienne Krauer, Lars Walløe, Ole Christian Lingjærde, Barbara Bramanti, Nils Chr. Stenseth and Boris V. Schmid. 2018. "Human Ectoparasites and the Spread of Plague in Europe During the Second Pandemic." Proceedings of the National Academy of Science 115(6):1304-09.

Elster, Jon and Ole-Jørgen Skog, eds. 1999. Getting Hooked: Rationality and Addiction. Cambridge, New York: Cambridge University Press.

Engene, Jan Oskar. 2005. Terrorism in Western Europe: Explaining the Trends since 1950. Cheltenham: Edward Elgar.

Engene, Jan Oskar. 2007. "Five Decades of Terrorism in Europe: The Tweed Dataset." Journal of Peace Research 44(1):109-21.

Fagan, Brennen, Marina Knight, Niall MacKay and A. Jamie Wood. 2018. "Change Point Analysis of Historical War Deaths." Vol.: University of York.

Fearon, James D. 1991. "Counterfactuals and Hypothesis Testing in Political Science." World Politics 43(2):169-95.

Fergusson, Niall. 2011. Virtual History: Alternatives and Counterfactuals Vol. Penguin: London.

Gershoff, Elizabeth T. 2017. "School Corporal Punishment in Global Perspective: Prevalence, Outcomes, and Efforts at Intervention." Psychology, Health \& Medicine 22(1):224-39.

Gleditsch, Kristian and Sara Polo. 2016. "Ethnic Inclusion, Democracy, and Terrorism." Public Choice 169(3):207-29.

Gleditsch, Kristian S. and Michael D. Ward. 1997. "Double Take: Reexamining Democracy and Autocracy in Modern Polities." Journal of Conflict Resolution 41(3):361-83.

Gleditsch, Kristian Skrede. 2004. "A Revised List of Wars between and within Independent States, 18162002." International Interactions 30( 4):231-62.

Gleditsch, Kristian Skrede and Kyle C. Beardsley. 2010. "Core Issues in International Data Collection." Pp. 4705-25 in International Studies Association Compendium of International Studies, Volume 17: Scientific Study of International Processes (Ssip), edited by P. F. Diehl and J. Morrow. New York: Wiley-Blackwell.

Gleditsch, Kristian Skrede and Steve Pickering. 2014. "Wars Are Becoming Less Frequent: A Reply to Harrison and Wolf." Economic History Review 67(1):214-30. 
Gleditsch, Kristian Skrede and Aaron Clauset. 2018. "Trends in Conflict: What Do We Know and What Can We Know?" in Oxford Handbook of International Security, edited by W. Wolforth and A. Gheciu. New York and Oxford: Oxford University Press.

Gleditsch, Nils Petter, Peter Wallensteen, Mikael Eriksson, Margareta Sollenberg and Håvard Strand. 2002. "Armed Conflict 1946-2001: A New Dataset." Journal of Peace Research 39(5):615-37.

Goldstein, Joshua S. 2011. Winning the War on War. Hialeah, FI: Dutton/Penguin.

Gray, John. 2015. "Steven Pinker Is Wrong About Violence and War." in The Guardian, 13 March, available at http://www.theguardian.com/books/2015/mar/13/john-gray-steven-pinker-wrongviolence-war-declining.

Guo, Weisi, Kristian Skrede Gleditsch and Alan Wilson. 2018. "Retool Ai to Forecast and Limit Wars. ." Nature 562(7727):331-33.

Harrison, Mark and Nikolaus Wolf. 2012. "The Frequency of Wars." Economic History Review 65(3):1055-76.

Hegre, Håvard, Lisa Hultman and Håvard Mokleiv Nygård. 2018. "Evaluating the Conflict-Reducing Effect of Un Peacekeeping Operations." Journal of Politics:in press.

Holt, Tracy Van, Jeffrey C. Johnson, Shiloh Moates and Kathleen M. Carley. 2016. "The Role of Datasets on Scientific Influence within Conflict Research." PLoS One 11(4):e0154148.

Human Security Report. 2007. "Humn Security Report 2007 - Dying to Lose: Explaining the Decline in Global Terrorism." Vol. Vancouver: Human Security Report Project.

Jaggers, Keith and Ted R. Gurr. 1995. "Tracking Democracy's Third Wave with the Polity Iii Data." Journal of Peace Research 32(4):469-82.

Kaldor, Mary. 2006. New Wars and Old Wars: Organised Violence in a Global Era, 2nd Edition. Cambridge: Polity.

LaFree, Gary and Laura Dugan. 2007. "Introducing the Global Terrorism Database." Terrorism and Political Violence 19(2):181-204.

Lebow, Richard Ned 2009. "Counterfactuals, History and Fiction." Historical Social Research 34(2):5773.

Mack, Andrew. 2002. "Civil War: Academic Research and the Policy Community." Journal of Peace Research 39(5):515-25.

Mann, Michael. 2018. "Have Wars and Violence Declined?". Theory and Society 47(1):37-60.

Manski, Charles F. 2013. Public Policy in an Uncertain World: Analysis and Decisions, Vol. Harvard University Press: Cambridge, MA.

Miranda, Luiz C. M., Leonel F. Perondi and Kristian Skrede Gleditsch. 2016. "The Evolution of Civil War Severity, 1816-2005." Peace Economics, Peace Science and Public Policy 22(3):247-76

Most, Benjamin A. and Harvey Starr. 1983. "Conceptualizing "War": Consequences for Theory and Research." Journal of Conflict Resolution 27(1):137-59.

Mueller, John and Mark G. Stewart. 2011. Terror, Security, and Money: Balancing the Risks, Benefits, and Costs of Homeland Security. Oxford and New York: Oxford University Press.

Mueller, John and Mark G. Stewart. 2015. Chasing Ghosts: The Policing of Terrorism. Oxford and New York: Oxford University Press.

Pinker, Steven. 2011. The Better Angels of Our Nature: Why Violence Has Declined. New York: Viking.

Polo, Sara M T and Kristian Skrede Gleditsch. 2016. "Twisting Arms and Sending Messages Terrorist Tactics in Civil War." Journal of Peace Research 53(6):815-29.

Preble, Christopher A. and John Mueller. 2014. A Dangerous World: Threat Perception and U.S. National Security. Washington, DC: Cato Institute.

Richardson, Lewis F. 1960. Statistics of Deadly Quarrels. Chicago, Pittsburgh, PA: Quadrangle/Boxwood.

Rosling, Hans. 2018. Factfulness: Ten Reasons We're Wrong About the World - and Why Things Are Better Than You Think. London: Sceptre.

Sambanis, Nicholas. 2004. "What Is a Civil War? Conceptual and Empirical Complexities of an Operational Definition." Journal of Conflict Resolution 48(6):814-58. 
Sandler, Todd. 2014. "The Analytical Study of Terrorism: Taking Stock." Journal of Peace Research 50(2):257-71.

Small, Melvin and J. David Singer. 1982. Resort to Arms: International and Civil Wars, 1816-1980. Beverly Hills, CA: Sage.

Taleb, Nassim Nicholas. 2007. The Black Swan: The Impact of the Highly Improbable. New York: Random House.

Tetlock, Phillip E. and Aaron Belkin, eds. 1996. Counterfactual Thought Experiments in World Politics: Logical, Methodological, and Psychological Perspectives. Princeton, NJ: Princeton University Press.

Theibault, John. 1997. "The Demography of the Thirty Years War Re-Revisited: Günther Franz and His Critics." German History 15(1):1-21.

United Nations and World Bank. 2018. Pathways for Peace: Inclusive Approaches to Preventing Violent Conflict:

Available

at

https://www.worldbank.org/en/topic/fragilityconflictviolence/publication/pathways-for-peaceinclusive-approaches-to-preventing-violent-conflict.

Vogt, Manuel, Nils-Christian Bormann, Seraina Rüegger, Lars-Erik Cederman, Philipp Hunziker and Luc Girardin. 2015. "Integrating Data on Ethnicity, Geography, and Conflict: The Ethnic Power Relations Data Set Family." Journal of Conflict Resolution 59(7):1327-42.

Zinnes, Dina A. 1976. "The Problem of Cumulation." in In Search of Global Patterns, edited by J. N. Rosenau. New York: Free Press. 